\title{
Causas e efeitos
}

\section{Causes and effects}

\section{Causas y efectos}

Ligia Bahia 1

Agradeço todos os comentários. Minha resposta está organizada em duas partes. Inicialmente pontuo apreciações, que suponho relevantes, realizadas por cada debatedor e a seguir delineio contra-argumentos que dialogam com críticas que foram recorrentes.

Claudia Travassos adverte que o setor privado tem capacidade de se "modificar", "recriar novos arranjos”. Portanto, não haveria propriamente novidades e sim uma reorganização empresarial. Considero que um moto-contínuo de recriação de arranjos do setor privado é um enunciado vago. O texto-debate expõe mudanças quantitativas e qualitativas no setor público, filantrópico e privado. Um arranjo privado setorial não é análogo ao movimento de inserção de instituições públicas e empresas da saúde nos circuitos internacionalizados das finanças. A autora critica ainda um suposto reducionismo das classificações sobre público, privado e filantrópico. De fato, os critérios utilizados para definir público, privado e filantrópico não estão detalhados, porém não são simplórios. Pelo contrário, o texto registra, com base nos valores de remuneração, a presença de três modalidades de público: público, público-organização-social e público com tabelas complementadas por estados e municípios; e três tipos de instituições filantrópicas, definidas por valores de remuneração e clientelas atendidas: filantrópico-SUS e planos, filantrópico-privado e filantrópico-SUS especializado em atendimento ao câncer.

Cristiani Vieira identifica a necessidade de reafirmar possíveis inconsistências ou equívocos em determinados equacionamentos. Julga que o reconhecimento constitucional da saúde alçou a cidadania para "outro patamar" e que "percalços e contradições" foram muitos e se expressam nas "relações entre público e privado". Recorda a existência de outras análises sobre o tema, que não ignoram mediações e escolhas políticas e ressalta a necessidade de atentar para a "agência". Parte desses apontamentos decorre dos traços e tensões ressaltados ou ocultos por reflexões orientadas pela teoria crítica ou pelo institucionalismo. O institucionalismo (que tem sido mobilizado com competência para analisar políticas de saúde) ressalta "contradições e percalços", na trajetória do SUS. Mas não constitui a única alternativa para analisar os 30 anos do SUS. É preciso contrarrestar uma inclinação ao individualismo metodológico 1 (incidente inclusive na produção acadêmica da área de Saúde Coletiva), nos incluir "dentro dessa" interação entre estrutura e agência e arriscar um diagnóstico para além do vai e vém de avanços e retrocessos. Sobre a existência de reflexões afins suponho tê-las respeitado e referenciado devidamente.
1 Faculdade de Medicina, Universidade Federal do Rio de Janeiro, Rio de Janeiro, Brasil.

\section{Correspondência}

L. Bahia

Departamento de Medicina Preventiva, Faculdade de Medicina, Universidade Federal do Rio de Janeiro. Praça Jorge Machado Moreira, Rio de Janeiro, $R J$ 21941-590, Brasil. ligiabahia@terra.com.br 
Hudson Pacifico da Silva sinaliza a "lógica subjacente ao capital de risco" que se contrapõe ao "desenvolvimento de inovações que podem gerar maiores benefícios sistêmicos". Julga que a análise sobre "modelos de negócios" e setores não diretamente ligados à prestação de serviços oferece uma chave explicativa, não acionada. Estou de acordo com as constatações sobre a indução de grandes mudanças provocadas por novas tecnologias e possíveis sinergias para transformar produtos, processos e gestão. Tenho apreço pelos raciocínios que alertam sobre as relações entre inovações e mudanças nos padrões de consumo, perfil do emprego e seus efeitos sobre a saúde. Assinalo, no entanto, que modelos de negócio, não apenas alavancam, mas também ameaçam empresas dominantes e que o trabalho realizado não se refere a esta temática.

Entre as apreciações críticas de Jairnilson Paim sobressai um questionamento central ao textodebate sobre omissões e indefinições relativas à perda de potência do bloco de centro-esquerda, responsável pelo processo de debates sobre a Reforma Sanitária. Ex-post, quando sempre é mais fácil justificar, considero que essa vereda está mapeada pelas análises sobre a Reforma Sanitária e que meu foco se dirigiu ao detalhamento do SUS. O texto atém-se ao movimento sanitário, mas fica devendo explicações sobre as conexões com o reposicionamento de partidos políticos e movimentos sociais e composição de alianças políticas. O encargo de completar a análise fica consignado.

Avalio que os assinalamentos de José Noronha sobre a "vertigem neo-liberal" estão bem claros no texto-debate, no qual a conjuntura não está demarcada apenas pela chegada e saída de determinadas coalizões governamentais à Presidência da República. A agressividade das "forças liberais" é um fato incontestável, mas deve estimular e não vedar estudos sobre os matizes dos processos sociais. Interpretações que reiteram a existência de um "sistema à parte múltiplo" "ordenado por uma agência reguladora atíica” são úteis. Determinados pesquisadores tomam as políticas públicas como ponto de partida para buscar entender o mercado. Outros tomam as empresas como unidade de observação para compreender as políticas públicas que lhes conferem suporte. Ambos os enfoques são valiosos, mas têm consequências políticas distintas. A reiteração sobre a separação entre dois sistemas e, sobretudo, o papel da ANS como articuladora-mor da segmentação recomenda sua imediata extinção e não a disputa entre forças políticas e conservadoras por seus cargos. O texto-debate detalha as políticas públicas que mantêm e expandem a desproporção entre a oferta e a demanda, demonstra que a segmentação da demanda para certas atividades não é radical e assim antecipa alternativas para regulação e regulamentação das interfaces público-privadas.

Luis Eugenio de Souza pondera que a "transição não acabou", "a disputa por projetos societários permanece aberta" e "o movimento da Reforma Sanitária segue atuante, se não vitorioso (...) [não está fora de combate]". Essa perspectiva fundamentada pela ética da conviç̧ão é benfazeja. No entanto, a situação concreta dos interesses econômicos, políticos e sociais em torno da saúde não é favorável a uma virada democratizante no curto prazo. Tenho imenso apreço pelas práticas movidas por convicções e vontades. Mas seria inoportuno escapar da responsabilidade de sistematizar uma análise realista sobre o SUS. Um projeto para a saúde que articule uma agenda democrática e democratizante requer táticas de curto e médio prazos e reconexão a projetos societários estratégicos de transformação social.

Três considerações estiveram presentes nos comentários de mais de um dos debatedores. A primeira seria um ajuste incorreto, injusto, entre o passado (1988 a 2002), ou ainda mais longínquo e os 13 anos de governos populares à frente da Presidência da República. Quem se vê diante da tarefa de refletir sobre a permanência (e é claro, continuidades e descontinuidades) de um fenômeno datado no tempo divisa dois caminhos. O primeiro é recusar o decurso temporal proposto: o que seriam trinta anos relativamente aos quinhentos anos de padrão extrativista e escravocrata? O texto-debate encarou a tarefa de refletir sobre trinta anos (poucos ou muitos) de SUS. Avalio que não podemos nos limitar a ser um país que enfatiza causas e menospreza efeitos, bem como identifico e afirmo a existência de políticas anti-SUS não cumulativas ao longo de 30 anos. A segunda concerne a uma apreensão equivocada sobre o potencial de um SUS democrático e democratizante para a redução de desigualdades que são estruturais. Presumo que o texto-debate não tenha avançado nenhuma certeza sobre o que poderia ter sido, apenas sistematizou informações sobre mudanças nas magnitudes dos setores público, privado e filantrópico e constatou tendências privatizantes de expansão. A terceira gravita em torno da cobrança de referências bibliográficas, não convocadas de meus estudos sobre privatização e financeirização, bem como de outros autores que enfatizam as características atuais 
do capitalismo. O SUS é um fenômeno distinto daquele que tem sido o objeto recorrente de meus estudos. Procurei encontrar abordagens e caminhos metodológicos estritamente adequados ao tema. Citações, inclusive autocitações, certamente estabelecem balizamentos para o debate, desde que não sejam argumentos de autoridade e dificultem disposições para convencer e sermos convencidos.

Muito obrigada pelas críticas e enriquecedoras contribuições ao texto. Espero que o debate continue e amplie.

1. Levine A, Sober E, Wright EO. Marxism and methodological individualism. New Left Rev 1987; (162):67-84. 